\title{
Neurological signs described at the Federal University of Rio de Janeiro: connecting the past to the future
}

\author{
Sinais neurológicos descritos na Universidade Federal do Rio de Janeiro: conectando o \\ passado ao futuro \\ Sofia Abreu MERMELSTEIN', Victor Evangelista Rodrigues PEREIRA', João Paulo da Costa GONÇALVES', \\ Flavio Henrique de Rezende COSTA ${ }^{1}$
}

\begin{abstract}
The Federal University of Rio de Janeiro (UFRJ) is one of the pillars of Brazilian Medicine and, in Neurology, has always shown prominence, with notable professors such as Antônio Austregésilo and Deolindo Couto. Historically, practitioners of the UFRJ Medical School have discovered neurological signs that, although used in medical and academic practice, have never been published. Objective: Our aim was to bring these signs to the forefront so that they become properly recognized and studied. Methods: We conducted our search by questioning 49 professors and physicians by e-mail about neurological signs that they remembered having had contact with at UFRJ. Results: We report on the unpublished pillow sign in progressive supranuclear palsy; the Brazilian sandal sign in functional or malingering patients; the dermographism sign in acute meningitis; the reverse forearm rolling sign in functional palsies; the cycling maneuver in parkinsonian syndromes and the Sá Cavalcanti sign, a Babinski equivalent. We have also recollected the following published signs for their historical relevance: the Austregésilo sign (Antônio Austregésilo), another Babinski equivalent; the digiti quinti rolling sign in subtle palsies (Péricles Maranhão) and the digiti quinti sign in hemiplegic migraine (Maurice Vincent). These signs are easily reproduced and have potential clinical applicability, deserving to be more thoroughly studied. Conclusions: Through a qualitative methodology, we have identified six original unpublished neurological signs known by the academic community, establishing the contribution of these individuals to the expansion of neurological semiology.
\end{abstract}

Keywords: Neurology, history; neurologic examination.

\section{RESUMO}

A Universidade Federal do Rio de Janeiro é um dos pilares da Medicina brasileira. Na Neurologia sempre se destacou com notáveis professores, como Antônio Austregésilo e Deolindo Couto. Historicamente, professores da Faculdade de Medicina da UFRJ descreveram sinais neurológicos que, embora utilizados na prática médica e acadêmica, nunca foram publicados. Objetivo: Fazer ressurgir sinais clínicos neurológicos nunca antes publicados, para que possam ser devidamente reconhecidos e estudados. Métodos: Quarenta e nove professores e médicos foram contactados por e-mail. Dez responderam questionário semi-estruturado acerca de sinais neurológicos conhecidos pelos profissionais, porém nunca publicados. Resultados: Foram relatados: 1- Sinal do Travesseiro - na Paralisia Supranuclear Progressiva; 2- Sinal da sandália- nos pacientes funcionais ou simuladores; 3- Sinal do dermografismo- nas meningites agudas da infância; 4- Sinal do rolamento reverso do antebraço- nas paralisias funcionais; 5- Manobra do pedalar- nas sindromes parkinsonianas; 6 - Sinal de Sá Cavalcanti- um sucedâneo de Babinski. Revisamos também os seguintes sinais publicados, por sua relevância histórica: o sinal Austregésilo, outro sucedâneo de Babinski; sinal do rolamento do quinto dedo- nas paralisias sutis e o sinal do quinto dedo- na enxaqueca hemiplégia. Conclusão: Por meio de metodologia qualitativa, identificamos seis sinais neurológicos inéditos originais. Esses sinais são de fácil reprodutibilidade e têm aplicabilidade clínica potencial, merecendo estudos adicionais.

Palavras-chave: Neurologia, história; exame neurológico.

\footnotetext{
1 Universidade Federal do Rio de Janeiro, Departamento de Neurologia, Rio de Janeiro RJ, Brasil.

Flavio Henrique de Rezende Costa (iD https://orcid.org/0000-0002-8801-9675; João Paulo da Costa Gonçalves (iD https://orcid.org/0000-0003-2621-3138; Victor Evangelista Rodrigues Pereira (iD) https://orcid.org/0000-0001-7147-6418; Sofia Abreu Mermelstein (iD) https://orcid.org/0000-0002-5292-4518 Correspondence: Flavio Henrique de Rezende Costa; Departamento de Neurologia da Faculdade de Medicina da UFRJ; Rua Rodolpho Paulo Rocco, 255 / $10^{\circ}$ andar, Iha do Governador; 21941-590 Rio de Janeiro RJ, Brasil; E-mail: fhrc76@gmail.com

Conflict of interest: There is no conflict of interest to declare.
}

Received 07 February 2019; Accepted 21 July 2019. 


\section{THE UNIVERSITY}

The Universidade Federal do Rio de Janeiro (Federal University of Rio de Janeiro - UFRJ), founded on November 5 , 1808 , is one of the pillars of Brazilian medical teaching and one of the most traditional universities in Brazil and Latin America $^{1}$. In the field of Neurology, the UFRJ has always been on the cutting edge and shown prominence in teaching since its time as the Escola de Anatomia, Medicina e Cirurgia (School of Anatomy, Medicine and Surgery), founded by John VI of Portugal in the Military Hospital of Morro do Castelo. It was later renamed Faculdade de Medicina (School of Medicine) in 1832 and, in 1856, transfered to Santa Luzia Street ${ }^{1}$. In 1918, its first own teaching-hospital building was inaugurated in the Praia Vermelha neighborhood and, shortly after in 1920, the medical school became known as Faculdade Nacional de Medicina da Universidade do Rio de Janeiro (the University of Rio de Janeiro's National School of Medicine). At this medical school, the first professor of Neurology was Dr. Antônio Austregésilo ("the father of Brazilian Neurology"), pioneer in the studies of movement disorders ${ }^{2,3,4}$. The university had its name changed to Universidade do Brasil (the University of Brazil) before its current denomination in 1965: Universidade Federal do Rio de Janeiro (the Federal University of Rio de Janeiro).

\section{THE FIRST PROFESSORS}

Memorable scholars have passed through the university's halls in its more than 200 years of history. In the preclassical period, José Martins da Cruz Jobim5 , who wrote Insânia Louquaz (Crazy Insanity) in 1831, the first text on mental illness in Brazil, and João Vicente Torres Homem ${ }^{6}$, considered the greatest name in Brazilian Medicine of the 20th century, responsible for the identification of the cerebral topography of various clinical manifestations. He was also known for bringing teachings from the French school of Charcot to Brazil, having written the first Brazilian book totally dedicated to neurology: "Lições sobre as moléstias do systema nervoso feitas na Faculdade de Medicina do Rio de Janeiro" (Lessons on the diseases of the nervous system made in the School of Medicine of Rio de Janeiro) (1878) .

The classical period began with the first chair of Neurology of the School of Medicine of Rio de Janeiro, headed by Antônio Austregésilo who, in France, attended the services of Babinski, Pierre-Marie and Dejérine. Austregésilo made numerous contributions to Neurology and to the study of movement disorders in Brazil, one of them being the world's first description of a post-traumatic dystonia patient, in addition to numerous other works of great worldwide recognition and prominence ${ }^{2,3,4}$. He is also known as the "spiritual father of Brazilian Neurosurgery”, for having appointed Augusto Brandão Filho and Alfredo Alberto Pereira Monteiro to officially start what eventually became the Escola Brasileira de Neurocirurgia (Brazilian School of Neurosurgery) 7 . Another highlight of this period was Professor Aloysio de Castro who, in his first book on neurological examination, Tractado de Semiótica Nervosa (Textbook of Nervous System Semiotics) (1914), revolutionized the teaching of the era bringing, for the first time, the use of photography as a learning tool, explored systematically in its pages. Prof. De Castro collected the vast material used in his book Policlínica Geral do Rio de Janeiro (General Polyclinic of Rio de Janeiro), in which he took hundreds of photographs and more than 130 films about gaits, movement disorders and other neurological examination aspects $^{8}$. He also exerted important academic activity in the Latin American scene, and it is worth mentioning his intense collaboration with Prof. Américo Ricaldoni, director of the Montevideo Medical School, Uruguay.

The second phase of the classical period had, as one of its major events, the foundation of the school of Deolindo Couto (one of the heirs of the school of Austregésilo and one of the founders and patrons of the Brazilian Academy of Neurology), who won with brilliance a contest to become the successor to Professor Austregésilo in the School of Neurology in $1945^{4,8}$. The Instituto de Neurologia Deolindo Couto (Deolindo Couto Neurology Institute), which is a part of the UFRJ hospital complex, was the epicenter of Brazilian Neurology under the management of Professor Deolindo Couto ${ }^{10}$.

The great capacity for clinical observation of these past scholars must be accounted for, as for more than a century, they observed and published several relevant neurological signs under the direct influence of the French school of Charcot Ch,11. $^{2,}$.

The main objective of this study was to identify these neurological signs that were never published by UFRJ's professors and physicians, bringing them to the forefront so that they can be the subjects of further studies. The secondary objective was to review the literature and identify neurological signs already published by UFRJ professors that have relevant historical and practical application.

\section{METHODS}

This was a qualitative study based on a survey conducted by e-mail directed to neurologists (professors and physicians) with an active or inactive link to UFRJ. As there was no direct participation of patients; use of medical records data or secondary sources of patient information, submission to the ethics and research committee was not needed.

Participants were invited to report neurological clinical signs described by professors or physicians at UFRJ that had never been published in scientific articles or textbooks.

Participants were asked to complete a table which contained the following information: name of the sign; 
approximate year of sign description (if known); name of UFRJ affiliate who described the sign and their specialty; brief sign description; clinical relevance and other important information.

Altogether, 49 neurologists were contacted. The forms with responses were received and analyzed individually and qualitatively. All of the cited physicians were contacted by a single investigator, who confirmed the sign's description and obtained additional data, such as the likely date of observation and additional information regarding its description. Signs not confirmed by the author or previously published were excluded from the results.

We also performed a literature review in the Pubmed database, which included the name of each professor of Neurology active at UFRJ, followed by the expression [Author]. The expressions "Deolindo Couto", "Neurology", "History", "historical aspects", "clinical description" and "Brazil" were used as search tools in different combinations. All relevant articles with original descriptions of clinical signs were included in the review.

\section{RESULTS}

\section{Unpublished signs (original)}

In total, 10 physicians answered the survey. The reported signs are summarized below with their mentioned professors:

\section{Professor Sergio Augusto Pereira Novis}

\section{The Pillow Sign (described in 2009 - one account)}

Patients with progressive supranuclear palsy tend to arrive for consultation with a pillow resting behind their head, to relieve retrocolis (abnormal dystonic posture often seen in patients with the Richardson form of progressive supranuclear palsy). It is a useful sign in the differentiation between atypical parkinsonisms.

\section{Professor Sergio Augusto Pereira Novis}

\section{The Brazilian Sandals Sign (described in the mid-2000s - one account)}

This sign consists of the assessment, through inspection by the clinician, of the characteristic appearance of sun exposure marks on the feet of patients who have worn narrow strip sandals (Havaianas sandals [flip-flops], very popular in Brazil). This clinical finding implies that the patient has been active and recently exposed to the tropical sun. Professor Flávio Costa noted that this sign is important in the evaluation of malingering or functional patients. These individuals sometimes complain they are bedridden and do not leave the house due to severe disability and, in spite of that, present with the sign, which can suggest an inconsistency.

\section{Professor José Luiz de Sá Cavalcanti}

\section{The Sá Cavalcanti Sign (1970s - five accounts)}

This is a useful maneuver that can be used in patients with a suspected pyramidal tract lesion.

The first stage of the maneuver consists of the examiner flexing the evaluated lower limb, while the patient is in a supine position, taking the heel of the foot to the level of the contralateral knee. In the second stage, the leg is extended at a constant speed, ensuring that the heel drags on the mattress during extension.

The sign is considered present if an extension of the hallux is seen. It is useful as an alternative to the plantar reflex, being a possible equivalent of the Babinski sign. It is particularly handy when no formal tools are available or safe, as in patients on contact isolation precaution.

\section{Professor James Pitágoras}

\section{The Dermographism Sign in acute meningitis (early 1980s - one account)}

In children with fever and malaise, but without clear physical signs of meningeal irritation on admission, the presence of dermographism on their skin while being examined by the doctor may indicate an acute meningeal infection in its early stages. Prof. Pitagorás observed that, in an emergency setting, the presence of this clinical sign could be regarded as additional information in the decision-making and diagnostic process. It could, therefore, be taken into consideration as

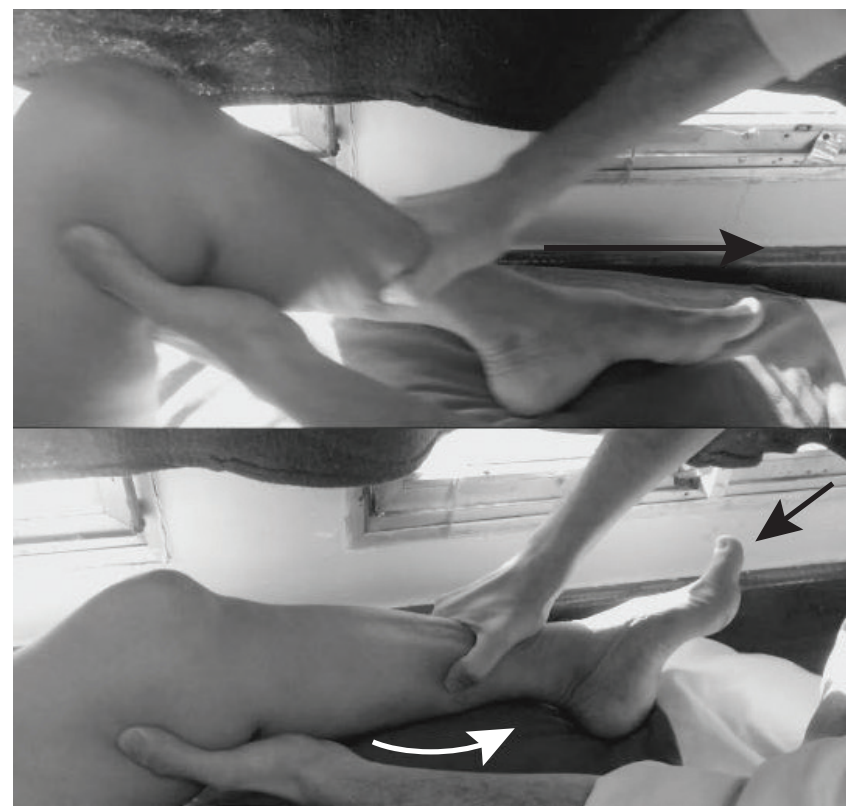

Figure 1. The Sá Cavalcanti sign. 
an aid to the physician's decision on whether that particular child, with an unclear and not yet fully established central nervous system infectious process, should proceed along that route of investigation and undergo lumbar puncture.

\section{Professor Flávio Henrique de Rezende Costa}

\section{The Reverse Forearm Rolling Sign (2009 - one account)}

In the investigation of subtle organic paresis, a typical test usually performed by clinicians in the examination is the forearm rolling test. The pathological response occurs when the unaffected arm orbits around the weak one (or, as the name states, rolls over it). A more sensitive variation of the same test, the finger rolling test, can also be used, the abnormal response being, likewise, when the normal finger orbits around the affected one. In patients with functional disorders, or, more prominently, in malingering patients, the opposite was observed. Prof. Costa recognized that, in these patients, the arm that is supposedly affected has a tendency to orbit around the strong one, which is a clear sign of inconsistency on examination. In addition, the patient may exhibit other clues that point towards a functional disorder or malingering, such as an exaggerated theatricality while performing the task. This clinical sign bears its significance, then, in the identification of these functional or malingering patients, who may come to the outpatient clinic or emergency department complaining of arm weakness.

\section{Professor Henryk Maultasch}

\section{The Cycling Maneuver (2014 - one account)}

With the patient sitting down on the bed or chair, their own hands placed by the side of their body for support, they are then asked to act as if they are riding a bicycle with their legs in the air, making large circular motions with their feet. The patient should perform this maneuver for 15 seconds as if they are riding said bicycle forwards, and for 15 seconds as if they are riding it backwards.

This maneuver is particularly useful in identifying lower limb bradykinesia in patients with a parkinsonian syndrome, especially as a way to determine if there is any asymmetry in the lower limbs.

It should be used as an accessory examination technique to the well-established foot-tapping maneuver in the assessment of bradykinesia. It is an important asset to the examination of lower limbs because, as opposed to the foot-tapping maneuver that can only properly and accurately evaluate one leg/foot at a time, this test can offer the examiner the chance to compare both legs simultaneously, making the distinction between them much clearer. If the patient does have asymmetric bradykinesia, the leg that is most compromised will, eventually, start making smaller circles than the other.

\section{PUBLISHED SIGNS}

\section{Professor Antônio Austregésilo}

\section{The Austregésilo Sign}

This sign was first published in the 1912 journal L'Éncephale, with the title Le phenoméne de Babinski, provoqué par l'éxcitation de la cuisse $e^{4,12}$. This sign can be sought via stimulation of the anterior or interior portion of the thigh (superficially

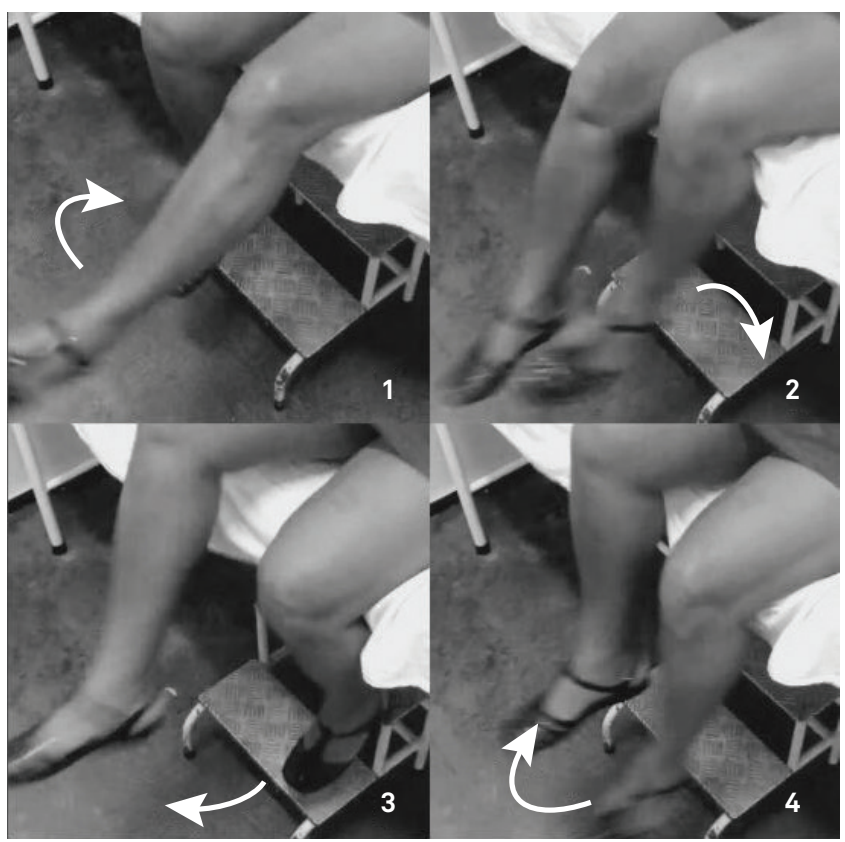

Figure 3. The cycling maneuver.

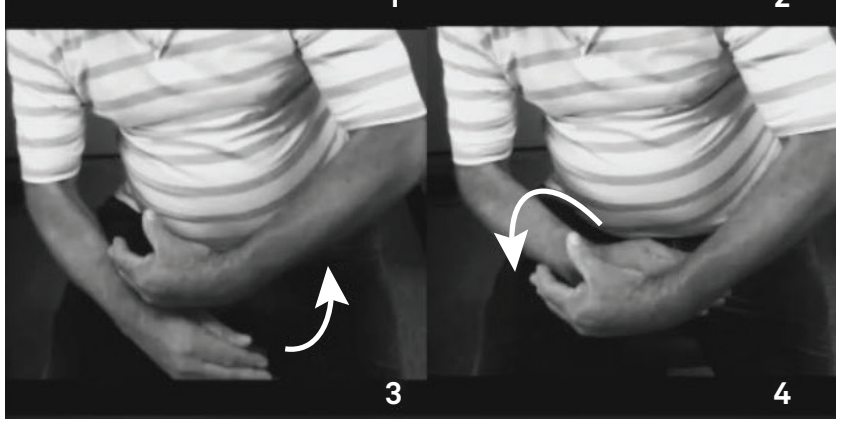

Figure 2. Reverse forearm rolling sign. 


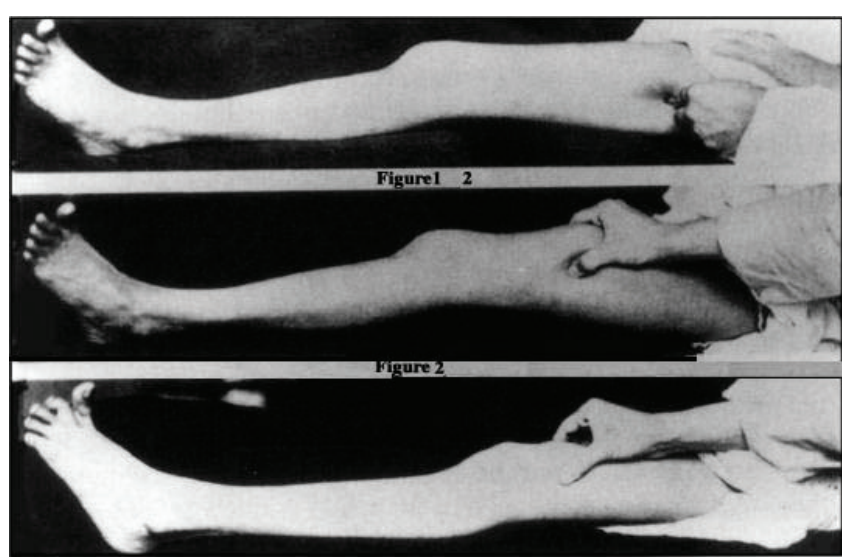

Figure 4. The Austregésilo sign

or deeply), and the expected response, in patients with pyramidal tract dysfunction, is an extension of the great toe and, eventually, fan-like spreading of the toes in the compromised leg. It is widely accepted as a Babinski sign equivalent.

\section{Professor Péricles de Andrade Maranhão Filho}

\section{The Digiti Quinti Rolling Sign}

Prof. Maranhão originally described the digiti quinti rolling sign as potentially useful, in a review article about the evolution of the neurologic examination, published in 2007 in the periodic Revista Brasileira de Neurologia (Brazilian Journal of Neurology) ${ }^{13}$. Prof. Maranhão, along with Prof. Marco Antonio Lima and Prof. Maurice Borges Vincent, then worked as co-authors on Dr. Eliana Maranhão’s paper entitled Can Clinical Tests Detect Early Signs of Monohemispheric Brain Tumors? ${ }^{14}$. In this paper, the authors demonstrated that the digiti quinti rolling sign had both high sensitivity and specificity in detecting subtle motor deficits in patients with monohemispheric lesions caused by brain tumors. The original sign's sensitivity was compared to that of other classical signs already proven to be useful in detecting subtle motor deficits. The digiti quinti rolling sign, together with the pronator drifting test and the finger rolling test, was the most sensitive, with its diagnostic accuracy surpassing that of the Babinski sign in the context of subtle motor deficits.

\section{Professor Maurice Borges Vincent}

\section{The Digiti Quinti Sign in Hemiplegic Migraine}

The digiti quinti sign was originally observed in the context of subtle motor deficits. It consists in a relatively larger abduction of the fifth finger contralateral to a pyramidal tract dysfunction affecting one arm, when the patient is asked to horizontally extend both arms with the palms facing the floor ${ }^{15}$.

This sign can also be observed in patients with hemiplegic migraine. In the interictal periods between migraine

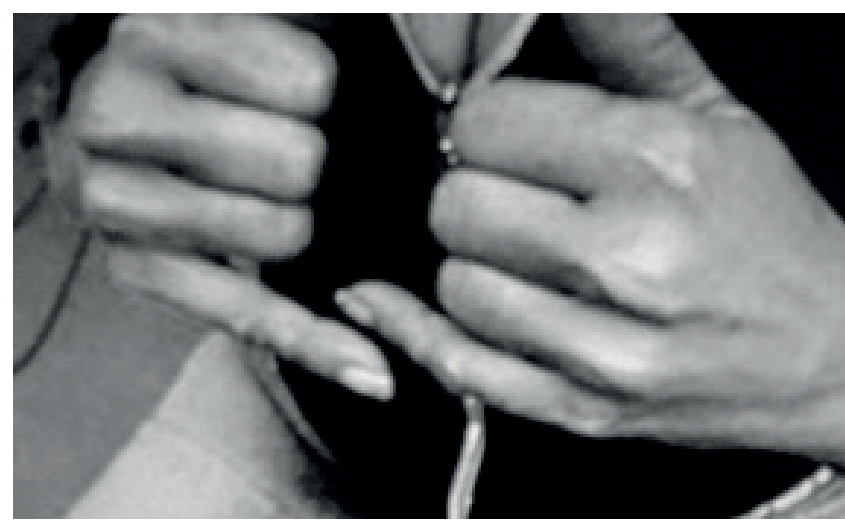

Figure 5. The digiti quinti rolling sign.

attacks the patient may present with no complaints or obvious deficits whatsoever, except for a remaining and persistent digiti quinti sign on examination, on same side that is symptomatic during their crisis ${ }^{16,17}$. Prof. Vincent's findings suggest that this sign is not exclusively found in patients with subtle motor deficits or mild paresis, as was previously thought.

\section{DISCUSSION}

Neurological semiology is still a dynamic and developing field of medicine, as this article has demonstrated. With a relatively simple-to-collect-and-analyze qualitative methodology, we managed to identify six never-before published neurological signs, all described by UFRJ professors. Some of these signs have, in spite of their still informal nature, been well known for years in the local academic community, although never formally recorded in the literature.

In the last few years, several new and original neurological signs and tests have been observed and published by several groups in different clinical settings. In spite of the rapid technological advances of the last decades in medicine, semiology is still expanding ${ }^{18,19,20}$. The insufficient number of journals and magazines dedicated to the description of new neurological signs, as well as the statistic rigidity of the methodology demanded by most editors may, in part, explain this scenario. There still are contrary movements to the status quo $^{21}$, but publishing on a purely qualitative methodological basis remains a challenge. It is worth noting that the sign many consider to be the single most important in neurology - the Babinski sign - was published by Joseph Babinski in February 22, 1896, in the form of a report as short as 28 lines of text, and has, since then, influenced the development of neurology as a whole ${ }^{22}$.

It is our understanding that one of the most important signs brought to light by our research, the Sá Cavalcanti sign, taught by generations of doctors as one of the Babinski 
equivalents, is not even mentioned by any recent literature on the subject ${ }^{23}$.

The absence of publications on new neurological signs deprives other physicians and health-care professionals of the opportunity to become acquainted with and use them, as well as restricting access to medical knowledge in a broader sense. It also prevents further and deeper study of these signs, with the important goal of determining their sensitivity, specificity, predictive values and diagnostic accuracy.

Four of the more recently discovered useful signs and tests, such as the pillow sign in progressive supranuclear palsy, the Brazilian sandal sign in malingering patients, the cycling maneuver in early stages/lower body parkinsonism, and the reverse forearm rolling sign in malingering/functional patients have shown promise and clinical applicability, and deserve to be more thoroughly studied.

We would like to highlight the potential of the dermographism sign in acute meningitis, observed by the prominent Prof. Pitágoras three decades ago. It is known that the diagnostic accuracy of meningeal irritation signs in children in the emergency department have proven to be very low ${ }^{24}$. The idea that a clinical test, as simple and easily observable as this one, is highly sensitive, and which could be used in an emergency room in the decision-making process, is a very attractive one, especially in such a vulnerable population as children. Therefore, we consider that the search for dermographism as an early sign of acute meningitis should be included in future works in the field, so that its accuracy can be assessed.

Finally, the limitations of this study should also be addressed. We have used a qualitative methodology in a study based on a survey method and a relatively small pool, although very representative of the acting neurologists in Rio de Janeiro and UFRJ. Qualitative studies can be valuable in collecting perceptions, opinions and practices ${ }^{25}$, but they are subject to several types of biases. Furthermore, we consider this study's findings to be the initial basis for a more solid series of studies, grounded in the use of proper, more rigorous statistical analysis, directed to the definition of the diagnostic accuracy and validation of each one of the aforementioned signs and tests.

To the best of our knowledge we have identified six new neurological examination signs and tests observed by professors of the Federal University of Rio de Janeiro. We advocate that these signs should be more thoroughly evaluated in the clinical practice setting, with the goal of assessing their diagnostic accuracy, thus validating them externally and internally as diagnostic tools to be added to the clinician's arsenal.

\section{References}

1. Teive H, Gomes M M. História da Neurologia Brasileira. Cinquentenário da Academia Brasileira de Neurologia. 1 a edição. São Paulo: Ominifarma; 2012.

2. Gomes MM, Cavalcanti JL. The Brazilian Neurology centenary (1912-2012) and the common origin of the fields of Neurology and Psychiatry. Arq Neuropsiquiatr. 2013 Jan;71(1):63-5. https://doi.org/10.1590/S0004-282X2013000100014

3. Gomes MM, Cavalcanti JL, Engelhardt E. French school of neurology in the 19th and first half of the 20th century, and its influence in Brazil. Arq Neuropsiquiatr. 2013 Oct;71(10):818-21. https://doi.org/10.1590/0004-282X20130129

4. Teive HG, Sá D, Silveira Neto O, Silveira OA, Werneck LC. [Professor Antonio Austregésilo. The pioneer of neurology and of the study of movement disorders in Brazil]. Arq Neuropsiquiatr. 1999 Sep;57 3B:898-902. Portuguese. https://doi.org/10.1590/S0004-282X1999000500030

5. Gomes MM, Engelhardt E, Chimelli L. The first Brazilian neuropsychiatrist, José Martins da Cruz Jobim, tuberculous meningitis and mental disease. Arq Neuropsiquiatr. 2013 Mar;71(3):191-3. https://doi.org/10.1590/S0004-282X2013000300012

6. Homem JVT. Lições sobre as moléstias do sistema nervoso. Rio de Janeiro; 1878.

7. Gusmão SS, Souza JG. The early history of neurosurgery in Brazil Neurosurgery. 2002 Jun;50(6):1336-40. https://doi.org/10.1227/00006123-200206000-00026

8. Maranhão-Filho P, Vincent MB, Silva MM. Neurological examination: pioneering authors and their books. Arq Neuropsiquiatr. 2015 Feb;73(2):140-6. https://ddoi.org/10.1590/0004-282X20140215
9. Wilson E. Aloysio de Castro and Uruguay .Arq Neuropsiquiatr. 2015 Feb;73(2):163-5. https://doi.org/10.1590/0004-282X20140208

10. Melaragno Filho R, Costa AL, Gomes MM [In memoriam: Deolindo Augusto de Nunes Couto (1902-1992). Arq Neuropsiquiatr. 1992 Sep;50(3):404-6. Portuguese. https://doi.org/10.1590/S0004-282X1992000300026

11. Teive HA, Munhoz RP, Lima PG, Germiniani FM. JeanBaptiste Charcot in Rio de Janeiro: glamorous trip and celebrity in 1908.Arq Neuropsiquiatr. 2015 Sep;73(9):809-11. https://doi.org/10.1590/0004-282X20150100

12. Wartenberg R. The Babinski reflex after fifty years.J Am Med Assoc. 1947;135(12):763.

13. Maranhão-Filho PA, Maranhão Et. The evolution of the Neurologic Examination and some signs described beginning in the XX century. Rev Bras Neurol. 2007;43(1):5-11.

14. Maranhão ET, Maranhão-Filho P, Lima MA, Vincent MB. Can clinical tests detect early signs of monohemispheric brain tumors?.J Neurol Phys Ther. 2010 Sep;34(3):145-9. https://doi.org/10.1097/NPT.0b013e3181e5c10e

15. Alter M. The digiti quinti sign of mild hemiparesis. Neurology. 1973 May;23(5):503-5. https://doi.org/10.1212/WNL.23.5.503

16. Vincent MB, Carvalho-e-Silva FM, Luiz RR. The digiti quinti sign in hemiplegic migraine .Cephalalgia. 2011 Jan;31(1):13-7. https://doi.org/10.1177/0333102410372424

17. Vincent MB. A note on the digiti quinti sign in hemiplegic migraine .Cephalalgia. 2009 May;29(5):580-2. https://doi.org/10.1111/j.1468-2982.2008.01743.x 
18. Dubois B, Slachevsky A, Pillon B, Beato R, Villalponda JM, Litvan I. "Applause sign" helps to discriminate PSP from FTD and PD. Neurology. 2005 Jun;64(12):2132-3.

19. Ling H, Massey LA, Lees AJ, Brown P, Day BL. Hypokinesia without decrement distinguishes progressive supranuclear palsy from Parkinson's disease .Brain. 2012 Apr;135(Pt 4):114153. https://doi.org/10.1093/brain/aws038

20. Cheng CJ, Mackinnon-Patterson B, BeckJL, Mackinnon SE. Scratch collapse test for evaluation of carpal and cubital tunnel syndrome.J Hand Surg Am. 2008 Nov;33(9):1518-24. https://doi.org/10.1016/j.jhsa.2008.05.022

21. Fiala C, Diamandis EP. The emerging landscape of scientific publishing .Clin Biochem. 2017 Aug;50(12):651-5. https://doi.org/10.1016/j.clinbiochem.2017.04.009
22. Babinski J. Sur le réflexe cutané plantaire dans certaines affections organiques du système nerveux central. CR Soc Biol. 1896;(48):207-8.

23. Drouin E, Drouin G, Péréon Y. The Babinski sign. Lancet Neurol. 2017 Mar;16(3):180. https://doi.org/10.1016/S1474-4422(16)30416-1

24. Waghdhare S, Kalantri A, Joshi R, Kalantri S. Accuracy of physical signs for detecting meningitis: a hospital-based diagnostic accuracy study. Clin Neurol Neurosurg. 2010 Nov;112(9):752-7. https://doi.org/10.1016/j.clineuro.2010.06.003

25. Safdar N, Abbo LM, Knobloch MJ, Seo SK. Research methods in healthcare epidemiology: survey and qualitative research. Infect Control Hosp Epidemiol. 2016 Nov;37(11):1272-7. https://doi.org/10.1017/ice.2016.171 